\title{
How journalism escorts daily life from Oltenia in years 1920-1930
}

\author{
Dan lonescu \\ "Nicolae Titulescu" High School, Doljului Street, Craiova, Romania \\ E-mail address: jonescus@yahoo.com
}

\begin{abstract}
The research is situated in the domain of the thematic history of the press. It approaches the topic of living, of the mundane existence of citizen's middle standard. Related to authorized views on this topic, the paper highlights: a) imagological inductions in everyday life, b) living in America of years 1920-1930 and Danish journalists' living analyzed at 1930 journalists from Oltenia, and c) the Romanian villagers life (in the range 1881-1937).
\end{abstract}

Keywords: journalism; thematic history of the journalism; objectivity and subjectivity in journalism

\section{INRODUCTION}

Imagological valences of the newspapers contributed to prediction of what is happening in the world. Looking into the magazines, regardless of the period in which they appeared, we will find out the attention that, only in a corner of the page, the editors have given a life from abroad. They caught in reviews, of what it was in other countries, the common points of their vision and ultimately, with the publication where they were employed.

The contacts with the other are shown as if they had occurred in his own language of I. We have to mention that still are relatively numerous foreignness linguistic influences of some Romanian texts in the first part of the nineteenth century (Dascălu, 2006, p. 22). For example, the newspaper "Mozaikul" was printed with "semichirilic alphabet" (Firan, 2007, p. 55). In postwar conditions, in which people want to take peace advantage and if cannot travel to places of which heard, then, to open a book, the market would need travel books, but the models were pressing and insurmountable: travel notes and memorials (Dinicu Golescu, Nicolae Filimon, Ion Codru Drăguşanu, Dimitrie Cantemir), journals (Titu Maiorescu, to whom the diary includes also the letters, Iacob Negruzzi, Liviu Rebreanu, Martha Bibescu), memoirs (Ioan Slavici, Nicolae Iorga, Sextil Puşcariu Matila Ghyka), correspondence (I.L. Caragiale, Ion Barbu, Tudor Vianu, to whom were considered also the journalistic pages) and, in the case of Mihai Eminescu, journalistic writings (Dascălu, 2006, p. 106).

More learned editors have developed a literature at the border between information and emotion, initiating comforting story, both for themselves, as they knew that, while they could not overcome the paradigm, still they served the faithfully public of the reportage, and for the readers eager of journey, but without financial capacity to carry out it, then a newspaper was the best guide. Later, in the eighties, the writer Radu Tudoran, seaman, had built a boat, with 
the intention to navigate. Not having received the right to leave the country, he began to sail on paper, to imagine adventures on the sea, thus to write the best novel for children in Romanian literature, "All sails above!"

\section{JOURNALISTIC REVEALING OF DAILY LIVING}

In the twenties of the last century, it was written about the reorganization of public reading in France: "Around every library, should organize conferences cycles to awake the taste of reading for the visitors" (Velicu, 1924, p. 380) (V. Velicu (1924). Cronica. Lamura. Revistă de cultură generală, 7-8, 380-382). Paris had "83 popular libraries maintained by the Municipality. Bucharest has none. During the war, curiously, the number of readers was two times higher than normal years. Even in those years has increased the number of libraries. People need consolation, a forgetfulness of encouragement in suffering. The soul shall find support in books, which was not to us "(Velicu, 1924, p. 380). The source of information is a booklet signed by Marcel Clavié, successful in era and translated into Romanian.

These view angles come after a war unprecedented destruction and express the moment curiosity on the changes of the world. The articles are like peeking over the fence, to neighbors, to see what they do to get better or, to have a justification in your business, find to others that they have done the same as you and neither not fail. Inevitable looking toward America led to the idea that was thought: "It will not be long and we will have also in big cities the schoolyard ... on the roof". Although commonplace today the idea has yet not found application to us, probably because different vision on how to do education (Smarandach \& Vlăduţescu, 2014).

How far seems America, its image. The newspapers were like a telescope (of Gulliver) toward the land of giants: "In New York where are skyscrapers houses with dozens of floors, it is understandable to climb the children on roofs to play between wire bars, like bears in the menagerie. But to us where is so much space, would be tolerable here such innovation required by needs? However, it is not far that day" (Mardan, 1924, p. 377) (Traian Mardan (1924). Cronica. Lamura. Revistă de cultură generală, 7-8, 377-378). He laments the lack of space in the great American city. From innocence of that unfortunately, the Americans would have not space and set up nursery blocks, it derive an implicit comparison that disadvantage us, but also the opinion about "The effects of alcohol prohibition in the United States" that at first seemed positive: "Drinking alcohol in all forms decreased at $2 \%$. The drunkenness offences from 1916 in New York reached the number of 16 355; in 1922, dropped to half, at 8765. Insanity of alcoholism decreased from $10 \%$ to $2-3 \%$. Tuberculosis and crime also decreased also with significant percentages. Those who benefit most are the children . For they are saved more money, they are healthy and their home is happier" (Mardan, 1924, p. 381).

"The Danish life" was still full of tradition and marked by two events, leaving on the sea, at fishing, where "they stay 7-8 months" (Modiga, 1934, p. 265), of men and sons, and returning to a such of our transhumance, but of which danger is not coming from the partner in activity, but the putties and sea storms.

Those left home, "cry them even soft, because fishing job is not easy. They fight with the terrible winds, the rage of waves and with the ringing frosts and many in place to hunt, they are swallowed by fishes". Periodically, the myth of Jonah displays Danish life and if the Bible would not be recorded, it would be appeared as one of the major myths of this northern country. The joyousness is revived in the sedentary part of the community, at returning home of fishermen: "They spend several days, visiting each other and wonder health, as all of them would be brothers" (Modiga, 1934, p. 266). The thought of those lost on the sea, even if they 
would not be related, retain them to be enthusiastic: "Their parties are not noisy as ours: it is a joy and gentle gladness. The organ is not missing from any home. When it was time for living, they greet the host and leave all, as a command. All parties are in family. Carousing with scandals are not mentioned" (Modiga, 1934, p. 266). Also their nature, is contrasting with physical appearance, "People tall, stout, blue-eyed, blond-haired, rough countenance, speaking of few words" (Modiga, 1934, p. 266), is special, quite balanced: "They are very polite people and they are balancing the words to not upset anyone. There, rich, poor, all are respected" (Modiga, 1934, p. 267). They are not telling exaggerated fishery stories, although some accidents on the sea, resulted tragic, exceeds the imagination. Culinary palette is specific: "buttery and fatty foods" (Modiga, 1934, p. 267) (D. Modiga (1934). Traiul danezilor. Naţionalul Vâlcii, 81-82, 265-267).

The harmony in community is fortified by common law custom, as sons, even if they are married, to live in the same house with the elders. In addition to be revered and surrounded by love, to seniors are distributed also enough activities, of those they can do, as well children's supervision: "At them children's care to be man of the right sort of timber, not anyway" (Modiga, 1934, p. 267).

The grange is well established and determines the envy even a "leader in from us detaining 10 hectares" (Modiga, 1934, p. 26). In 1934, in Denmark, a family having "2 hectares of sand area detains: 4 healthy horses for work, 8 cows - but cows, not like us -, 10 pigs, 300 chickens of great variety, beautiful and good, 100 geese and 80 ducks. And how much brings in!" (Modiga, 1934, p. 267). Efficiency remained a feature of the Danish people, but this way described here may lack him; in his own introspection, it would never have seen thus. Religious life is captured in its simple aspects: "On Sunday morning everybody goes to church, (...) The church is great, but is not decorated like us. It has not separated altar. Priest is serving openly. People sit on benches, read each one the missal in thought that each one brings it from home. Sometimes they stay in knees in banks, 3 to 4 times and all of them sings. Their organ plays nice, slower or louder, creepy. How sweet are they in the church: silence, calmness and listening! Nobody even looked up from the book even to look at neighborhood. All on time and nobody leaves early. The Pastor preaches long and beautiful. Even the preach is the most important of the church service and all the people listen to it in great peace" (Modiga, 1934, p. 266).

The relationship with the world, with the discovery in technical or fashion in music, in art generally, occurs in Volkkultur: "In the afternoon, all are going to Volkkultur (House of people culture, n.n.), which is a large palace even it is in a village, with a large theater hall, with seats where people stand comfortable, with several rooms around, some of them with books - library - others kinds of way of old and new things, exhibition, museum" (Modiga, 1934, p. 267). The teacher or another literate „makes a speech, and then they sing the chorus 3-4 voices, singing music, it gives an educational film by cinema, all of these having the goal of teaching and spending the soul uplifting. No one is forced to go there, but cannot someone missing, though is paying an entrance fee. Everyone goes there to learn, for reading and have fun at the same time. For them the highest duty is to learn. It is not written in any law that debt, but it's in their nature, cannot live without learning" (Modiga, 1934, p. 267).

Denmark, the country of cooperatives, of universities of the popular village "where the Grundtvig teacher was a propeller of today welfare, has the richest and most flourishing export homestead (Siminică \& Traistaru, 2013; Dima \& Vlăduţescu, 2012). Undoubtedly is the country with the most literate peasants. Nearly a quarter of students are in secondary schools and technical. This share did not have any country in the world, second only England has 5\%. They learn high school and then this young come back in the most natural, to field 
work"(Velicu, 1924, p. 379). In the Romanian village, the most important commitment, as it is reflected in the novel "Ion", by Liviu Rebreanu, they had the teacher and the priest, who has often disputed the primacy of the village, with attracted adherents by turns, with specific precepts of their profession.

It catalogues in Denmark case, the difference attenuation between urban and rural: "The village, which may have up to 10000 inhabitants and are others much more, has paved streets, clean sidewalks and 2-4 rows of fruit trees on edges. Most of houses are two floors, with many chambers and small because there the wind is terrible humming and they love the heat. Also in stables and birds they have stoves. The village seems a nice little town. There are 4 schools and 4 kindergartens, the school is clean and warm, the children wear only flannel all the same" (Modiga, 1934, p. 267).

The report, as many of the category, is written with the idea that many, authentic fact to that time when the TV was utopia, have the opportunity to know, maybe through the radio, but concise, more so, on the ground, Denmark. The focus is on inconsistent facts with what we knew, inhabitants of a space undulatory: "Denmark is a miniature country, surrounded only by water. As you look with your eyes it's sandy plain" (Modiga, 1934, p. 265). For most of the Romanian, accustomed to plan and to judge everything in harmony with the firm specific of each of the four seasons, boreal climate would have been a curiosity, today certainly diminished of Internet or other information multiple ways, but then, in 1934, exacerbated by the attitude of editor who takes as good everything that seems unusual, to impress the readers. Alternation: "There the winter takes eight months and summer four" and intensity: "In winter, snow and more rain and frost that you slip into the house, in summer enough large heat, but the sun does not burn like us, does not beat down" (Modiga, 1934, p. 265) today are more specific to Canada.

Here the livelihood of the villagers, whose basic occupation was agriculture, technically, looks something like this. Drinking water, almost in all villages of the plain, was got "from the watershed wells and a bucket. These wells are cheaper and easier to do, but not enough clean, as are those with wheel and two buckets because many of those who come to get water does not have clean hands or neither are healthy" (Daniilescu, 1937, p. 15). The water in villages "between of hills and mountains is healthy, already taken from the fountains where water flows continuously, it coming on further or closer on tile or tubes from several sources gathered in a covered water treasury and so protected of dust and dirt". The culverts were fashionable. To protect the water from them, it were proposing all sorts of methods, such as paving. There was an excessive fear, but justified, to some contagious diseases as scarlet fever, and even syphilis; it were done surveys on rural crossing diseases.

The next detail, although unlikely today, is revealing for the town opening of the Romanian village at that time, regarding the desire for individualization of consumption: "There are many villages that have the water so far brought in pipes and every householder pays annually - as city - a sum of money for maintenance of the treasury and pipes through which comes water into the village" (Daniilescu, 1937, p. 16).

The parallel with the city highlights the rapid postwar progress (after WWI) of the city beside the village: "When the houses in the cities are large, of wall and large windows through which to enter the sun, because they are made by municipalities approved plans, to villages are almost all from the way before the war: small rooms and short windows $60 \mathrm{on} 40 \mathrm{~cm}$ with iron lattice and often unopened for months, with the ground floor of brick or beaten earth and long beds and bedding only by one blanket or rug or mats. Few of the villagers, especially those who are part of village officials and intellectuals make their homes with high and large rooms, with windows that open for ventilation and cleaning, with floor of washed planks several times 
throughout the year and particularly the home kitchen separated of the house where they live, work and sleep" (Daniilescu, 1937, p. 16).

The task of progressive change, the villagers living, to give them advices was carried out by the teachers and the doctors; in conferences and popular lectures, they talked about the benefits "sleeping of a few in room"(Daniilescu, 1937, p. 16) and about the danger to human health, when they "keep in the house young animals, clucking hen under the beds, you they do not paved chambers when not whitewashing the walls on the inside and outside of 2-4 times per year" (Daniilescu, 1937, p. 17). The perspective: "Through the work and diligence he (the villager, n.n.) can live as a city dweller, the only difference is that the city dweller maintains the good life with great expense" (Daniilescu, 1937, p. 17) (C. Daniilescu (1937). Traiul săteanului. Naționalul Vâlcii, 109-110, 15-19 is still valid today.

Always there is the opinion that it was better before. Confessions about the life inside of the community made more writers. They had a strong nostalgia for the old living in cottage: "The father's cottage was not made quite of diligent man, but it was the good stuff. It had the hallway (sometimes called the cottage porch, entrance houses, n.n.) wide and tall - not like of the grandfather or Stancu Jianu crone, in shack, it breaks your spine when you enter it (Stavre, 2012; Vlăduţescu, 2014).

The cottage had no porch, but it had wide and gross beams to sustain the cottage or house rafters: the eight beams compose the eaves of house, strong and of oak. Poles on cottage, braced with poles, broad beech, well carved over her cane and above ground. The pillars of cottage, broad and of beech well bulged on them raupo and above earth. On the pillars, mother had limed, she made a kind of flowers that we the children compared them with wolves, greyhounds, stallions and other creatures (Drămescu, 2013, Postmodern Society and Individual Alienation. Journal of Experiential Psychotherapy / Revista de PSIHOterapie Experientiala. 16(3), p. 55-58.). The cottage had also cellar - a small spaces between hearth and stove - where were preserved food as in a pantry. Hearth was in the room at the entrance, which is called pad, and back room, which served the living and sleeping and which had also glass window and was called stove. People really need, instead of glass to the window, sticked paper (Bobeanu, 1931, p. 211). The cottages were lighted by gas lamps. Most "lighted by shard: - a bowl in which put pork fat; in the fat floated a rag that lights at the top, which we cast out on the shard edge. It lighted rather weak in lickers and snapping" (Bobeanu, 1931, p. 212).

The cottage as it rises on 1881, when it was believed very much in the newspapers, of what they conveyed, and the auxiliary invention of domestic labor was not yet prepared to industrial scale. Some children saw a creature in the newspaper: "Lie of predators - endowed with an imagination of the richest - tells us, the children, that gazette it's a large frog, as a bushel with many legs. When it move the legs, by signs that they do show that at Easter, earth is sinking" (Bobeanu, 1931, p. 211). A news about the end of the world was able to mess up an entire village, whose individuals developed in their households, a veritable textile industry, but feared of fatalistic posts or only pretended, to initiate in folklore, new themes, modern, inspired from the enthusiasm of science (Bărbulescu, Țâţu \& Țâţu, 2007). Extravagant information awaited breathless, opened breaches between people. On the "beginning of March 1881 it was rumored in the village that on the approaching Easter, Earth will sink. All those who were enemies of a lifetime, now reunited, they have forgiven between them, all of them entertained, in faith that the end of the world was near"(Bobeanu, 1931, p. 213). Naivety that coagulates was not primordial, not because of it people cames together. They were tolerant of disposition and were characterized of the wisdom that life, also without calamity, is short.

Children have suffered the most because of the possible end of the world because they really would have lost a heaven: "We had cut it all joys at the thought that no longer we will 
not stay at the sun on mats, not going to catch butterflies with wormwood field, it will not play birds in the grandfather's garden, will not walk to spring flowers on the grass field, we will never cry in unison to mention, when we have drunken wine from small hods, in an old woman advice, who arranged the tables on mentions: God will forgive whom he commemorates!" (Bobeanu, 1931, p. 214) (I. Bobeanu (1931). Viața de la 1880. Gazeta Școalei, 9-10, 211-213).

In winter, with snow drift such as the house, the stuffiness in the village did not take long. The peddlers, "with merchandise quiver on his back," filled the streets with the cry: "Mart, Mart. From them, we the kids bought, either buck or with bristles flutes, and cotton rings and girls, earrings and cestoids" (strips of silk made in factory and that are used as ornament in female clothing, men's hats, sustained chest decorations and so on) (Bobeanu, 1931, p. 214).

\section{CONCLUSIONS}

From the comparison with former times I do not know if we today, are in advantage. In dialogue with a local archaeologist, I expressed our sympathy to the ascending of Cucuteni civilization or others, how difficult it will be to endure the manifestation of nature, so cold, winter, or so hot in the summer, and what will be eaten, poor of them! Archaeologist changed my point of view. "Digging, he said, I found homes, solid stoves to which they heated and made press bread. Look, He showed me a painted clay pot, the paint that burns them is thousands of years old and it is not taken.

Do you realize what sunrises or sunsets have got them? The sun will never go back to the blue that it went up in the sky then ... The forests swarmed with buffalo. As they entered in the forest, they found buffalos and hunt hunted them. They feasted of fresh meat. An entire village eats a buffalo, a hearty". The only dangers, we set both, would be the discords between them and other nations invasion over their settlement".

The author himself of above article inserts some of the disadvantages of time that he lived, the thirties of last century, beside to that of his childhood spent in 1880 or so: "But winter! God what a beauty of birds: tufted skylark, goldfinch with blue feathers and finch with yellow wings with green spots and red throat, that we dragged to bran with snares made of horsehair. Today all the birds have almost disappeared. There are not hens, wild fowls, field duck, who swarmed on the sprawling plains in that time" (Bobeanu, 1931, p. 212).

It remains to be investigated the villagers living from us, in the spiritual side and to understand why philosophers and thinkers of the time, including Constantin Radulescu-Motru who holds leading position, were supporters of the traditional village, to keep in it, things resulting from concepts.

\section{References}

[1] B. M. Dascălu (2006). Germanitatea şi literele române. Bucureşti: Editura Fundaţia Culturală Ideea Europeană.

[2] I. Bobeanu (1931). Viața de la 1880. Gazeta Școalei.

[3] Andrzej Borowski, International Letters of Social and Humanistic Sciences 11 (2014) $1-168$.

[4] Maria Nowicka-Scowron, Ioan Constantin Dima, Ştefan Vlăduţescu, International Journal of Management Sciences and Business Research 1(8) (2012) 27-35. 
[5] Andrzej Borowski, International Letters of Social and Humanistic Sciences 2 (2014) 110-121.

[6] M. G. Mangra, E. A. Cotoc, A. Traistaru (2013). Sustainable Economic Development Through Environmental Management Systems Implementation. Journal.

[7] Andrzej Borowski, International Letters of Social and Humanistic Sciences 4 (2013) $70-74$.

[8] Ştefan Vlăduţescu, Ella Magdalena Ciupercă (2013). Next Flood Level of Communication: Social Networks. Aachen: Shaker Verlag.

[9] Andrzej Borowski, International Letters of Social and Humanistic Sciences 3 (2013) 69-74.

[10] Ştefan Vlăduţescu, International Letters of Social and Humanistic Sciences 10(2) (2014) 100-106.

[11] C. Daniilescu (1937). Traiul săteanului. Naționalul Vâlcii.

[12] Florea Firan (2004). Presa literară craioveană. Craiova: Scrisul Românesc.

[13] Ştefan Vlăduţescu (2006). Comunicare jurnalistică negativă. Bucureşti: Editura Academiei.

[14] Traian Mardan (1924). Cronica. Lamura. Revistă de cultură generală,

[15] D. Modiga (1934). Traiul danezilor. Naționalul Vâlcii.

[16] Ştefan Vlăduţescu (2013). Message as Fundamental Discursive Commitment of Communication. Journal.

[17] Dumitru Vladut (1998). Figuri sintactice repetitiv-adjunctive In stilul stiinfific romanesc din secolul al XIX-lea. Filologie.

[18] V. Velicu (1924). Cronica. Lamura. Revistă de cultură generală.

[19] Ioan David (2013). Presă şi cultură (Press and Culture). Timiţoara:David Print.

[20] Ştefan Vlăduţescu (2013). Three Diachronic Paradigms of Communication. International.

[21] Marin Drămnescu (2013). Postmodern Society and Individual Alienation. Revista de PSIHOterapie Experienţială.

[22] J. Tittenbrun, International Letters of Social and Humanistic Sciences 2 (2014) 20-40.

[23] Ioan Constantin Dima, Ştefan Vlăduţescu (2012). Persuasion elements used in logistical negotiation: Persuasive logistical negotiation. Saarbrucken: LAP Lambert Academic Publishing.

[24] R. Bărbulescu, D. Ţâtu, L. Țaţu (2007). Investment in human capital. EU integration opportunities, Romania within EU: opportunities, requirements and perspectives (pp. 430-435). V1. Sibiu: Editura Universităţii Lucian Blaga.

[25] I. Stavre (2012). Internet and digital technology - influences on audiovisual communication and on teaching at master's degree level, Valencia, 2012, Published by International Association of Technology, Education and Development, ISBN: 978-84-615-5563-5. 
[26] Ştefan Vlăduţescu (2014). Eight Computational-Communicative Operations of Building Information. Mitteilungen Klosterneuburg

[27] A. Borowski, International Letters of Social and Humanistic Sciences 4 (2013) 70-74.

[28] Ştefan Vlăduţescu (2013a). A Completion to the Traditions Matrix-Standard - R. T. Craig, Induced by the Transformation of Communication-as-a-Field Membrane in Communication-as-a-Universe Membrane. American International.

[29] Mihaela Gabriela Paun (2013). Changes in Management as an Instrument of Educational Intervention. European.

[30] Ştefan Vlăduţescu (2013). Communicative Message as Nuclear Thinking of an Aspirational Desire. In I. Boldea (Coord.), Studies on Literature, Discourse and Multicultural Dialogue (pp. 212-217). Târgu Mureş: Editura Arhipelag XXI.

[31] Jason L. Powell, International Letters of Social and Humanistic Sciences 7 (2014) 22-30.

[32] Borowski A., International Letters of Social and Humanistic Sciences 6 (2013) 86-90.

[33] Ştefan Vlăduţescu, International Letters of Social and Humanistic Sciences 7 (2014) 8-13.

[34] Marian Siminică, Aurelia Traistaru (2013). Self-Directed Learning in Economic Education. International.

[35] Florentin Smarandache, Ştefan Vlăduţescu (2014). Neutrosophic Emergences and Incidences in Communication and Information. Saarbrucken: LAP Lambert Academic Publishing.

[36] Donovan A. McFarlane, International Letters of Social and Humanistic Sciences 4 (2013) 35-44.

[37] Kinga Dziwańska, International Letters of Social and Humanistic Sciences 7 (2013) 96-112.

[38] Stefan Freytag, International Letters of Social and Humanistic Sciences 10 (2013) 25-31.

[39] Ștefan Vlăduțescu (2013b). Câștig și pierdere de informație în analiza de intelligence. Fuziune, fisiune, comunicare. În G. C. Maior \& I. Nițu (Coord), Ars Analytica. Provocări și tendințe în analiza de intelligence (pp. 309-327). București: Editura Rao.

[40] Iulian Bitoleanu, International Letters of Social and Humanistic Sciences 9 (2014) 161-121.

[41] Dan Ionescu, Cristina Pretorian, International Letters of Social and Humanistic Sciences 9 (2014) 49-56.

[42] Ştefan Vlăduțescu (2013a). De ce s-ar numi ce facem noi aici Istoria presei românești /Istoria jurnalismului din România/ și pentru ce? În R. Bîlbîie, F. Șperlea; M. Teodor (Coord), Jurnalismul, o preocupare a elitei. Studii și cercetări de istorie a presei (pp. 19-25). București: Editura Tritonic.

[43] Mădălina Strechie, International Letters of Social and Humanistic Sciences 7 (2014) 56-61. 
[44] Alexandra Iorgulescu, International Letters of Social and Humanistic Sciences 7 (2014) 14-21.

[45] A. Borowski, International Letters of Social and Humanistic Sciences 2 (2013) 56-60.

[46] Peter Emerson, International Letters of Social and Humanistic Sciences 10(2) (2014) 132-155. 